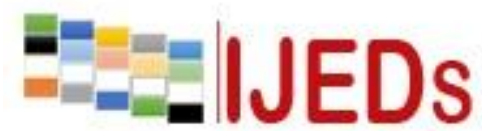

http://ijeds.ppj.unp.ac.id/index.php/IJEDS

\title{
DEVELOPMENT OF STUDENTS' WORKSHEETS BASED ON PROBLEM- BASED INSTRUCTION (PBI) OF GRADE X SENIOR HIGH SCHOOL
}

\author{
* Elvira Diana. S $\mathbf{1}$, I Made Arnawa ${ }^{2}$, and Ratnawulan ${ }^{3}$ \\ ${ }^{1}$ Graduate Program Techonology of Educations, Universitas Negeri Padang \\ ${ }^{2}$ Postgraduate Lecturer Mathematical Educations, Universitas Negeri Padang \\ ${ }^{3}$ Postgraduate Lecturer Physics Educations, Universitas Negeri Padang \\ Email: ochy.oliviaoktorie@gmail.com \\ *Corresponding Author, Received: November 12, 2019, Revised: December 10, 2019, Accepted: December 21, 2019
}

\begin{abstract}
This study is intended to produce senior high school students' mathematical worksheets based on valid, practical and effective problem-based instruction. Its effectiveness can be seen from the increase in positive activity and student learning outcomes. It is research and development by using the Plomp model by using three stages, namely the preliminary research, development or prototype phase, and assessment phase. The subjects were students of class X SMAN 1 Lembah Gumanti. The research instruments were interview guidelines, field notes, validation sheets, student and teacher response questionnaires, students' activity observation sheets and learning achievement tests. This research has produced students' worksheets that are valid, practical and effective. Students and teachers give a good response of students' worksheet because it helps them in the learning process. Students can learn efficiently and understand the mathematical concepts easily. Students' worksheet can also motivate students in learning so that there is enhancement between positive activities and learning outcomes. Keywords : Problem Based Instruction, Students' Worksheet, Senior High School,
Valid, Practical, Effective.
\end{abstract}

\section{INTRODUCTION}

The problem of education is closely related to the problem of learning. Learning is one element in the implementation of education. Therefore, the quality of education is closely related to the quality of learning. Creating innovations or new breakthroughs in the world of education is one of way to improve the quality education especially in learning activities. It can reach certain aspects of a person in order to develop his potential optimally. 


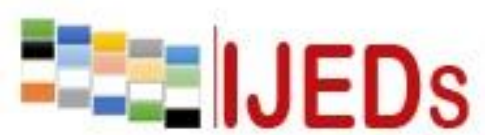

http://ijeds.ppj.unp.ac.id/index.php/IJEDS
International Journal of Educational Dynamics

Vol. 2 No. 1 (pp. 30-43) Desember 2019

p_ISSN 2655-4852

e_ISSN 2655-5093

Learning in schools consists of a variety of knowledge that delivered through subjects. Each subject has its own role in developing students' potential. Mathematic is one of significant subject is taught in the school. It can be seen in the objectives of mathematics learning. The learning objectives of mathematics according to the 2013 Ministry of Education and Culture are (1) enhancing intellectual abilities, especially high-level students 'abilities, (2) forming students' abilities in solving problems systematically, (3) obtaining high learning outcomes, (4) training students in communicating ideas -ide, especially in writing scientific papers, and (5) developing student characters [1]. Therefore, learning mathematics must be carried out well so that the learning objectives of mathematics can be achieved to the maximum.

There are some results of observations at SMAN 1 Lembah Gumanti in class X. 1) students are less focused when learning takes place, 2) students' understanding of the concept of the material is still low, 3) students have difficulty in solving story problems or problem solving questions, 4) students ask questions and express their opinions during learning embarrassedly, 5) students have difficulty in understanding student books from the government.

Common questions are usually given to students by teacher. It makes students are difficulties in doing different questions with teachers' example. This learning cause students are not active and independent. It also cause students wait for answers from the teacher. Related, students only accept and lack understanding in constructing or making their own knowledge in solving mathematical problems presented in the subject matter. Circumstances that continue to make students will remain bored and less motivated in learning mathematics. This makes the classroom conditions issued and there is no interaction between students in learning.

The interview results from teacher indicate that students have not been able to solve the story questions properly. Students have difficulty in understanding the material, identifying, and simplifying questions in the form of story questions. The results of interviews from students indicate that most students only study math at school mathematics without repetition when at home. Students consider mathematics is a difficult subject to understand. 


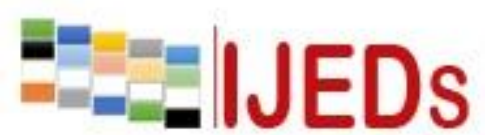

http://ijeds.ppj.unp.ac.id/index.php/IJEDS
International Journal of Educational Dynamics

Vol. 2 No. 1 (pp. 30-43) Desember 2019

p_ISSN 2655-4852

e_ISSN 2655-5093

The process of learning mathematics should emphasize the involvement of students in utilizing mathematics through a process, not results-oriented. This causes the ability of students to understand concepts, create or formulate, identify, interpret and plan problem solving and be able to apply concepts in different situations to be undeveloped

Based on the analysis conducted on students' worksheets, it is seen that the presentation of material in students' worksheets is directly at the core of the material, students are immediately given the concept of the subject matter. In students' worksheets it is not supported yetby activities that actively involve students in making discoveries to build concepts on the material being studied. The lack of involvement of students in building their own knowledge resulted in students tending to memorize formulas and students easily forget about the formula. This contrasts with the original purpose of students' worksheets being used. Prayitno [2] said students' worksheets can be used to convey concepts to students who aim to improve understanding of concepts. The designed students' worksheets must help students in learning and make it easy to understand the concept [3]. To overcome the problems that occur in learning mathematics in the classroom, an effort is needed in selecting models and teaching materials in learning. Teachers are required to be more creative, innovative, placing students not only as learning objects but as learning subjects and ultimately lead to an enjoyable learning process.

Problem-based instruction cause students can get fun learning with interactive classes. It is suitable for creating a good learning environment. This is in line with research conducted by Golightly and Raath [4] stating in PBI that the teacher should create a problem based on desired curriculum outcomes, student characteristics, and real-world situation and Kamin, O'Sullivan, Younger and Deterding [5] states PBI is based on methods designed to promote skills in critical analysis, self-directed learning, and problem solving.

In addition, the learning model based on Problem Based Instruction can also improve students' learning activities and learning outcomes. This opinion is in line with the results of research Listiowati (2013) [6] states the learning model Problem Based Instruction with the Predict-Observe-Explain approach has a positive effect on 


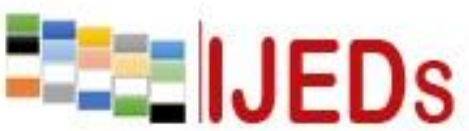

http://ijeds.ppj.unp.ac.id/index.php/IJEDS
International Journal of Educational Dynamics

Vol. 2 No. 1 (pp. 30-43) Desember 2019

p_ISSN 2655-4852

e_ISSN 2655-5093

chemistry learning outcomes, Dewi (2016) research results [7] states that the application of the Problem Based Instruction model in the Development Economics course can improve student learning outcomes at UM Metro, and Nasriani's research results (2019) [8] states that the application of the Problem Based Instruction model can increase activeness in class X of SMK Negeri 1 Majene.

Trianto [9] said that Problem Based Instruction is problem based teaching that begins with the teacher introducing students to problem situations and ending with the presentation and analysis of student work. The problem presented is a problem that is relevant to the real world of students. The problems given aim to motivate students, arouse students' learning enthusiasm, increase student learning activities, learn to focus on problem solving so that students are interested in learning, and find concepts that are appropriate to the subject matter. Thus, students more easily solve problems from given problems. In addition, PBI is a learning model based on constructivist understanding that accommodates student involvement in authentic learning and problem solving. Weist [10] Problem-oriented teaching methods support learners in finding their own solutions to substantial and relevant problems. Students who are oriented towards a problem will make them find relevant solutions, this is because students practice to find a way out independently without the help of the teacher. The purpose of this study is to produce a worksheet based on Problem Based Instruction for class $\mathrm{X}$ high school students that is valid, practical and effective.

\section{METHOD}

This research is a research development. According Richey and Nelson development research as a systematic assessment of the design, development and evaluation of programs, processes, and learning products that must meet the validity, practicality, and effectiveness criteria [11]. The development model used is the Plomp model. The Plomp model consists of three stages, namely preliminary research, development or prototyping phase and assessment phase [12]. Product design evaluations are carried out in each phase. The development phase is shown in Table 1.

Table 1. Development Phase

Phase Activity Description




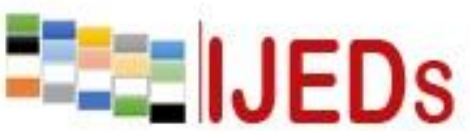

http://ijeds.ppj.unp.ac.id/index.php/IJEDS
Preliminary Needs analysis, curriculum analysis, concept analysis and student research analysis
Development/ Evaluation of the prototype in terms of validity, which is done through Prototyping self-evaluation and expert review. After revision, it continues with Phase practical assessment through one-on-one evaluations and small group evaluations

Assessment Assess whether the product is practical and effective through a field phase test

This phase uses formative evaluation. According to Tesmer [12] there are four stages of the formative evaluation process, namely, 1) expert review, 2) one-to-one, 3) small groups, and 4) field test.

\section{RESULTS AND DISCUSSION}

The results of the preliminary research are divided into the results of needs analysis, curriculum analysis results, concept analysis results and student analysis results. Results of needs analysis: based on observations it is known that learning that has taken place so far is still dominated by the teacher as the information center. Learning material is presented not yet involving students to find their own concepts so that the learning outcomes obtained by students are still low. One factor that causes this is the unavailability of learning tools that can facilitate students to be active in learning, one of them is the Student Worksheet. A good student worksheet will be able to guide and facilitate students to be more active and creative in learning. In addition, since the enactment of the 2013 curriculum the government has facilitated both teachers and students with teacher books and student books. The results of the analysis of the student book shows that students still have difficulty in understanding the problems contained in the book.

One alternative solution to these problems is to provide learning tools, especially teaching materials in the form of student worksheets that can support the achievement of desired learning goals. Trianto [9]told that students worksheets are student guides used to conduct inquiry or problem solving activities aimed at developing cognitive aspects as well as guidelines for developing all aspects of learning in the form of experimental or demonstration guides. Meanwhile, Prastowo [13] states that the student worksheets are teaching materials that have been packaged in such a way that students are expected to be able to study these teaching materials 


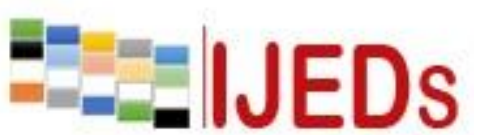

http://ijeds.ppj.unp.ac.id/index.php/IJEDS
International Journal of Educational Dynamics

Vol. 2 No. 1 (pp. 30-43) Desember 2019

p_ISSN 2655-4852

e_ISSN 2655-5093

independently. One learning model that can facilitate students to improve motivation, activities and students' understanding of mathematical concepts is Problem Based Instruction.

Through Problem Based Instruction-based student worksheets, students can develop thinking skills, problem solving and intellectual skills, and become independent learners [9]. In addition, student worksheets that are developed must be able to attract the attention of students to use them, because based on interviews conducted with several students it can also be concluded that students want interesting teaching materials, meaning that the student worksheets provided have attractive colors and not boring. Curriculum analysis results: Curriculum analysis is carried out on Geometry material. At this stage, there are no changes to the Basic Competencies and Competency Achievement Indicators used by the school. Results of concept analysis: after analyzing concepts based on 2013 curriculum class X material even semester consisting of geometry, trigonometry, algebraic function limits, statistics and probability. Geometry material was chosen as material for student worksheets that were developed.

Results of student analysis: Class X students become the subject of research in testing student worksheets based on Problem Based Instruction. The analysis was conducted on class X students of SMAN 1 Lembah Gumanti. The first characteristic obtained is that students are in the formal operations stage. The students are aged in the range of 15-16 years. Piaget [14] states, at the age of 15-16 years the cognitive development possessed by a child is at the stage of formal operations. At the formal operation stage, children are able to solve problems, and reason using abstract things. The use of concrete objects is no longer needed. The second characteristic of students, based on interviews and observations made, it is known that students are more comfortable learning with peer tutors. This can be seen when the learning process takes place, if students do not understand the subject matter taught by the teacher, then students prefer to ask questions with their friends. According to students, asking friends who understand can help them understand the material being studied.

The third characteristic of students is that when the learning process of students lacks concentration, they do not even focus on paying attention to the teacher's explanation. Students prefer to tell stories with their peers. This is because learning is 


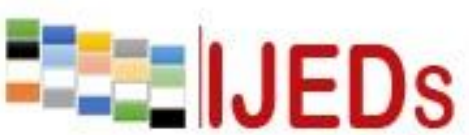

http://ijeds.ppj.unp.ac.id/index.php/IJEDS
International Journal of Educational Dynamics

Vol. 2 No. 1 (pp. 30-43) Desember 2019

p_ISSN 2655-4852

e_ISSN 2655-5093

more focused on the teacher as a source of information. The fourth characteristic of students is that most students like to group when doing work, for example, go shopping to the canteen or go somewhere. This character shows that students prefer to do an activity together.

Based on the characters found, the researchers felt the need to develop student worksheets based on Problem Based Instruction that could accommodate the characters possessed by students in a positive direction in the learning process. Problem Based Instruction student worksheets are learning resources that can accommodate the characteristics of students who like to discuss, and are not focused on what is conveyed by the teacher during the learning process. Learning by using student worksheets based on Problem Based Instruction invites students to be active starting from the beginning of the learning process. In addition, students are also taught steps to solve problems. If there are students who prefer to study individually, Problem Based Instruction-based student worksheets will also guide students to actively construct their knowledge independently.

\section{Expert Review Results}

The student worksheets developed were assessed by 5 experts, namely 2 mathematics lecturers, 1 language lecturer, 1 educational technology lecturer and 1 mathematics teacher who aimed to provide an assessment and input on Problem Based Instruction-based worksheets. The results of expert evaluations of the products developed can be seen in Table 2 .

Table 2. Validity of Worksheet Student

\begin{tabular}{clcc}
\hline No & Aspect of Validation & Validity Indeks & Category \\
\hline 1 & Didactic & 3,32 & Very Valid \\
2 & Content & 3,50 & Very Valid \\
3 & Language & 3,67 & Very Valid \\
4 & Presentation & 3,52 & Very Valid \\
& Average & $\mathbf{3 , 5 0}$ & Very Valid \\
\hline
\end{tabular}

Table 2 shows that the assessment for each aspect of the Problem Based Instruction-based student worksheet is very valid. The indicators contained in the didactic aspect are 5 indicators with an average rating of 3.32 in the very valid category. Indicators on the aspect of content there are 4 indicators with an average rating of 3.50 are in the category of very valid. Indicators in the aspect of language there are 3 


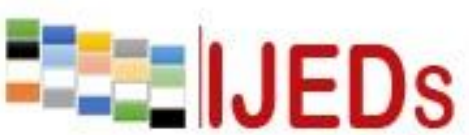

http://ijeds.ppj.unp.ac.id/index.php/IJEDS
International Journal of Educational Dynamics

Vol. 2 No. 1 (pp. 30-43) Desember 2019

p_ISSN 2655-4852

e_ISSN 2655-5093

indicators with an average rating of 3.67 in the category of very valid. There are 5 indicators in the presentation aspect with an average of 3.52 in the very valid category. Overall the average assessment of students' worksheets developed was 3.50 with a very valid category.

Problem Based Instruction based student worksheets are declared valid because Problem Based Instruction based worksheets are very well designed so that each activity contained in the student worksheet is meaningful to students. In addition, the components contained in the student worksheets are in accordance with the indicators set on the validity instrument so that after processing the data obtained an average score of validity of the student worksheets based on Problem Based Instruction in the very valid category. This Problem Based Instruction-based student worksheet was also developed according to aspects of measuring validity that meet the content validity and construct validity. Student worksheets meet the validity of the contents means that the development of student worksheets has been based on theories that are the basis for preparing a student worksheet. Student worksheets meet the construct validity meaning that the development of student worksheets has paid attention to the interrelationship of the components in the student worksheet. Messick [15] explains the construct validity of covering: 1) content; 2) substantive; 3) structural; 4) external; and 5) the consequences. The language on the student worksheets is also commutative, the presentation of the material has fully led to the learning outcomes that are formulated, the questions contained on the student worksheet are in accordance with the material presented.

\section{One-to-One Evaluation and Small Group Evaluation Results}

Student worksheets were tested for three students with high, medium and low abilities. Students are asked to try to understand the instructions on the student worksheet. They are asked to give suggestions about concepts, problems, pictures, illustrations, and existing questions. Information is collected by observing while students do it. Students find some typos and dubious words. After conducting one-toone evaluations, revisions are made according to errors found by students during the one-to-one evaluation process. Then the evaluation continues with the evaluation of a small group by practicing the worksheet designed for a group of students. The evaluation was conducted on 6 students with heterogeneous abilities. Students are 
(\%)

\begin{tabular}{lllr}
\hline 1 & $\begin{array}{l}\text { Practicality of student worksheets } \\
\text { presentation }\end{array}$ & 93,75 & Very practical \\
2 & $\begin{array}{l}\text { Ease of Use of student worksheets } \\
\text { The time needed to work on the student }\end{array}$ & 90,71 & Very practical \\
& $\begin{array}{l}\text { worksheet } \\
\text { Average }\end{array}$ & Very practical \\
& $\mathbf{8 9 , 8 2}$ & Very practical \\
\hline
\end{tabular}

Table 5. Teacher's Response to Student Worksheets

\begin{tabular}{|c|c|c|c|}
\hline No & Aspect & $\begin{array}{l}\text { Percentage } \\
(\%)\end{array}$ & Category \\
\hline 1 & $\begin{array}{llll}\begin{array}{l}\text { Practicality } \\
\text { presentation }\end{array} & \text { of } & \text { student } & \text { worksheets }\end{array}$ & 93,75 & Very practical \\
\hline 2 & Ease of Use of student worksheets & 91,07 & Very practical \\
\hline 3 & $\begin{array}{l}\text { The time needed to work on the student } \\
\text { worksheet }\end{array}$ & 100,00 & Very practical \\
\hline & Average & 94,94 & Very practical \\
\hline
\end{tabular}

Table 3, Table 4, and Table 5 show that the percentage of assessments given by students and teachers to student worksheets based on Problem Based Instruction ranged from $85 \%-100 \%$. Overall the worksheets of the students developed are in the very practical category. This means that students' worksheets have elements that attract the attention of students and teachers.

Problem Based Instruction-based worksheets are declared practical because the worksheets of students as a whole are very interesting, both in terms of content and appearance, developed student worksheets can guide and assist students in understanding the material being studied. The problem given is also quite simple so that it can involve students to obtain the material being studied themselves. Student worksheets are also equipped with pictures that can be found by students in everyday life. Display of colors, pictures, and writing on student worksheets can increase students' curiosity and improve their understanding of the concept. According to students, the worksheets of the students developed are new and interesting and are able to make them to learn independently, interactively, challenge and motivate students in the learning process. The entire display on the student worksheet can make students become active and enthusiastic in following the learning process. Students argue that they prefer learning to use student worksheets based on Problem Based Instruction because it is easier to understand the material. In general, students' responses to the 


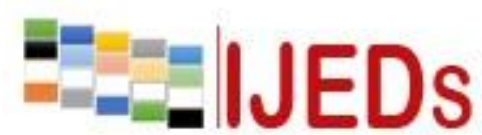

http://ijeds.ppj.unp.ac.id/index.php/IJEDS
International Journal of Educational Dynamics

Vol. 2 No. 1 (pp. 30-43) Desember 2019

p_ISSN 2655-4852

e_ISSN 2655-5093

Problem Based Instructions student worksheets were very good. So, it can be concluded that overall the worksheet of students based on Problem Based Instruction is appropriate for use in learning.

\section{Effectiveness Results (Field Test)}

The results of the effectiveness of the worksheets of students can be seen from the observation data of students 'activities while using the worksheet based on Problem Based Instruction and the students' final test results after the students use the entire worksheet based on Problem Based Instruction. Observation of the activities and final tests carried out in small group evaluation activities and field test. The final test given was a 5-item description question. Observation data of students' activities while using Problem Based Instruction based student worksheets is presented in the following bar diagram.

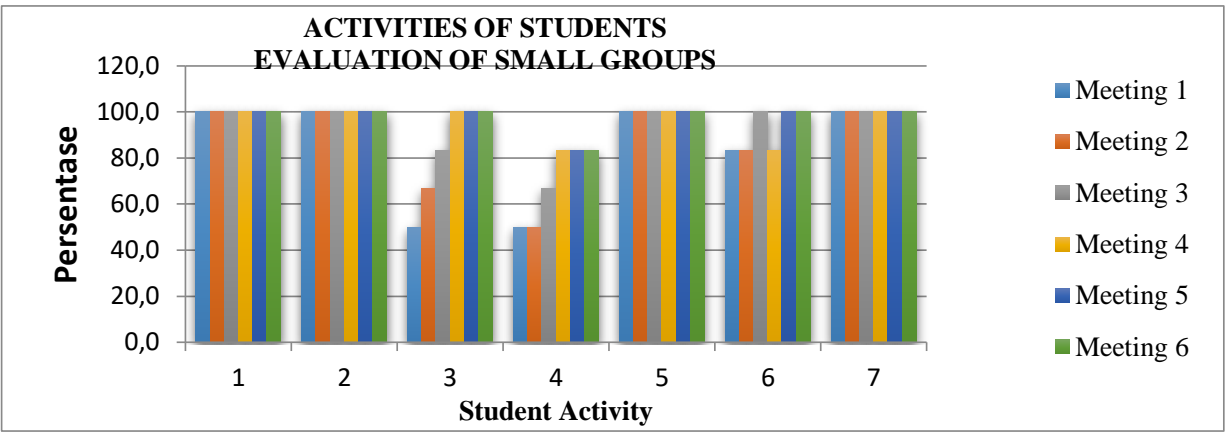

Figure 1. Bar Diagram of Student Learning Activity in Small Group Evaluation

In Figure 1, it can be seen that the percentage of student activity lies in the many and many categories with a range of percentages of $50 \%$ to $100 \%$. These seven activities tend to increase for each meeting, one of them is the motivation provided by the teacher. This means that the use of student worksheets based on Problem Based Instruction in the small group evaluation stage can increase student learning activities.

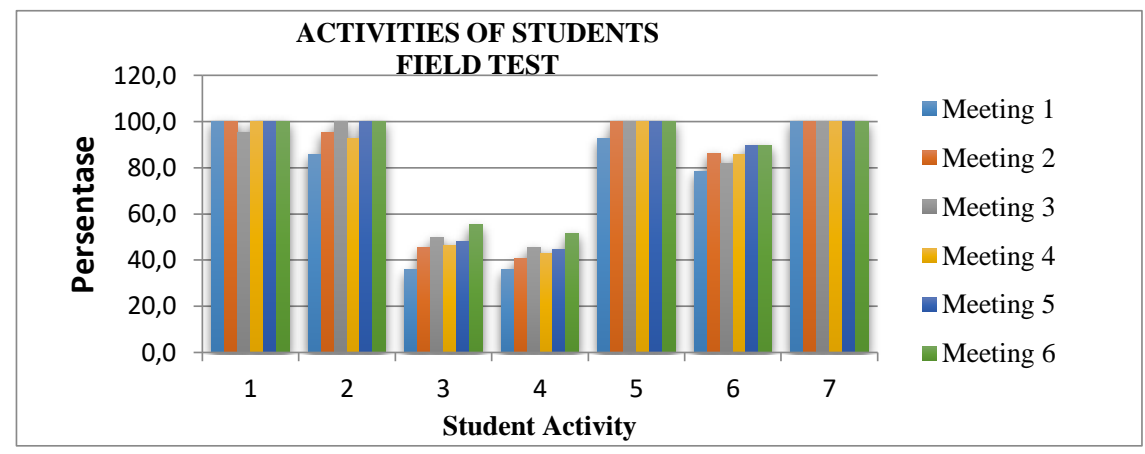

Figure 2. Bar Diagrams of Student Learning Activity Field Test 


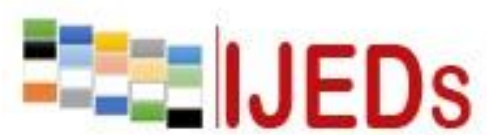

http://ijeds.ppj.unp.ac.id/index.php/IJEDS
International Journal of Educational Dynamics

Vol. 2 No. 1 (pp. 30-43) Desember 2019

p_ISSN 2655-4852

e_ISSN 2655-5093

In Figure 2, it appears that the activities of students points 3 and 4 (student activities asking questions and expressing opinions in learning) in general are still relatively small. However, at each meeting the activity has increased, one of which is the motivation given by the teacher. In addition, the activities of students for the five other activities included in the category of lots and lots with a range of percentages of $78.6 \%$ to $100 \%$. These five activities tend to increase. This means that the use of student worksheets based on Problem Based Instruction in the field test stage can increase students' mathematical learning activities. Based on the final test results from KBM (Minimal Learning Completeness) in class X mathematics set at SMAN 1 Lembah Gumanti is 80 then the percentage of completeness obtained $83.33 \%$ with a good category of 6 people who took the final test. Meanwhile, the field test obtained $76.67 \%$ completeness percentage with a good category of 30 people who took the final test. From the results of this final test, it is known that more than $75 \%$ of students are above the Minimum Learning Criteria. Thus it can be concluded that the learning outcomes of students after using a worksheet based on Problem Based Instruction increases. This shows that the workaround of students based on Problem Based Instruction has been effective for improving student learning outcomes

Problem Based Instruction based student worksheets are declared effective because learning using student worksheets can increase positive activity and student learning outcomes. It is also inseparable from the role of the teacher who always motivates students in various activities carried out by students.

\section{CONCLUSION}

Based on the process and results of the research that has been done, the conclusion of this study is that the student worksheet is based on Problem Based Instruction:

1. Applies in terms of contents and construction.

2. Practical in the aspects of implementation, convenience and time required.

3. Effective in increasing positive activities and student learning outcomes. 


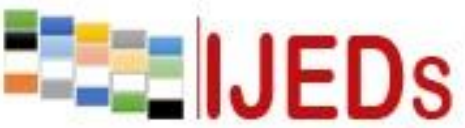

http://ijeds.ppj.unp.ac.id/index.php/IJEDS
International Journal of Educational Dynamics

Vol. 2 No. 1 (pp. 30-43) Desember 2019

p_ISSN 2655-4852

e_ISSN 2655-5093

\section{REFERENCES}

Dewi, Tiara Anggia. Penerapan Model Problem Based Instruction untuk Meningkatkan Hasil Belajar Mahasiswa pada Mata Kuliah Ekonomi Pembangunan. PROMOSI: Jurnal Program Studi Pendidikan Ekonomi, 2016, 4.1.

Golightly, A., \& Raath, S. (2015). Problem-Based Learning to Foster Deep Learning in Preservice Geography Teacher Education. Journal of Geography, 114(2), 58-68. https://doi.org/10.1080/00221341.2014.894110.

Kamin, C. S., O’Sullivan, P. S., Younger, M., \& Deterding, R. (2001). Measuring Critical Thinking in Problem Based Learning Discourse. Teaching and Learning in Medicine, 13(1), 27-35. https://doi.org/10.1207/S15328015TLM13016.

Kemendikbud. (2013). Kerangka Dasar dan Struktur Kurikulum 2013. Jakarta: Kemendikbud.

Listiowati, Ayu Dwi, and Antonius Tri Widodo. "Penerapan model pembelajaran problem based instruction dengan pendekatan Predict-Observe-Explain." Jurnal Inovasi Pendidikan Kimia 7.2 (2013).

Nasriani, N., Slamet Widodo, and S. Syamsidah. "PENINGKATAN KEAKTIFAN SISWA KELAS $X$ PADA MATA PELAJARAN K3 DAN SANITASI HYGIENE MELALUI MODEL PEMBELAJARAN PROBLEM BASED INSTRUCTION (PBI) DI SMK NEGERI 1 MAJENE." Prosiding Seminar Nasional Sinergitas Multidisiplin Ilmu Pengetahuan dan Teknologi. Vol. 2. 2019.

Permendikbud. PP Nomor 69 Tahun 2013 tentang Stuktur Kurikulum SMA/MA. Jakarta: Permendikbud.

Plomp, T. dan N. Nieveen. (2013). Educational Design Research. Enschede: Netherland Institute for Curriculum Development (SLO).

Prastowo, Andi. (2011). Panduan Kreatif Membuuat Bahan Ajar Inovatif. Yogyakarta: DIVA Press.

P. Susongko, "Validation of science achievement test with the Rasch model," $J$. Pendidik. IPA Indones., vol. 5, no. 2, pp. 268-277, 2016.

Prayitno, E dan Mahmudi, A. (2003). Media Pembelajaran Matematika. Yogyakarta: UNY.

Sudjana, N dan Ahmad R. (2003). Teknologi Pengajaran. Bandung: Sinar Baru Algensindo.

Trianto. (2009). Mendesain Model Pembelajaran Inovatif-Progresif: Konsep, Landasan, dan Implementasinya pada Kurikulum Tingkat Satuan Pendidikan (KTSP). Jakarta: Kencana.

“The Integrative Learning Design Framework: Educational Design Research," no. July, pp. 114-133, 2014.

Weiss, G. (2017). Problem-Oriented Learning in Geography Education: Construction of Motivating Problems. Journal of Geography, 116(5), 206216.

Suherman, Erman, dkk. (2003). Strategi Pembelajaran Matematika Kontemporer. Bandung: Universitas Pendidikan Indonesia. 
International Journal of Educational Dynamics

$==-=\mid J E D S$

http://ijeds.ppj.unp.ac.id/index.php/IJEDS
Vol. 2 No. 1 (pp. 30-43) Desember 2019

p_ISSN 2655-4852

e_ISSN 2655-5093 